Meta

Journal des traducteurs

Translators' Journal

\title{
Describing Phraseological Devices in Medical Abstracts: An English/Spanish Contrastive Analysis
}

\section{Belén López-Arroyo et Beatriz Méndez-Cendón}

Volume 52, numéro 3, septembre 2007

URI : https://id.erudit.org/iderudit/016735ar

DOI : https://doi.org/10.7202/016735ar

Aller au sommaire du numéro

Éditeur(s)

Les Presses de l'Université de Montréal

ISSN

0026-0452 (imprimé)

1492-1421 (numérique)

Découvrir la revue

Citer cet article

López-Arroyo, B. \& Méndez-Cendón, B. (2007). Describing Phraseological Devices in Medical Abstracts: An English/Spanish Contrastive Analysis. Meta, 52(3), 503-516. https://doi.org/10.7202/016735ar
Résumé de l'article

La typologie des genres s'intéresse prioritairement à la structure rhétorique des études de recherche. Cependant, les théoriciens n'ont pas étudié systématiquement les relations entre les genres ni les études interlinguistiques. Cette étude vise à décrire et à comparer les structures rhétoriques et phraséologiques de résumés en anglais et en espagnol afin de déterminer la façon dont l'information est transmise. Notre méthodologie concerne un corpus de résumés dans le domaine de l'imagerie diagnostique des revues de renom. Nous utiliserons les stratégies de composition d'une approche sémantique et fonctionnelle pour établir leurs ressemblances et leurs différences. Nos résultats serviront aux traducteurs, aux rédacteurs techniques et aux étudiants des LSP afin de mieux comprendre certains éléments discursifs de transmission d'information scientifique dans les deux langues. 


\title{
Describing Phraseological Devices in Medical Abstracts: An English/Spanish Contrastive Analysis:
}

\author{
BELÉN LÓPEZ-ARROYO \\ University of Valladolid, Valladolid, Spain \\ belenl@lia.uva.es \\ BEATRIZ MÉNDEZ-CENDÓN \\ University of Valladolid, Valladolid, Spain \\ cendon@lia.uva.es
}

\begin{abstract}
RÉSUMÉ
La typologie des genres s'intéresse prioritairement à la structure rhétorique des études de recherche. Cependant, les théoriciens n'ont pas étudié systématiquement les relations entre les genres ni les études interlinguistiques. Cette étude vise à décrire et à comparer les structures rhétoriques et phraséologiques de résumés en anglais et en espagnol afin de déterminer la façon dont l'information est transmise. Notre méthodologie concerne un corpus de résumés dans le domaine de l'imagerie diagnostique des revues de renom. Nous utiliserons les stratégies de composition d'une approche sémantique et fonctionnelle pour établir leurs ressemblances et leurs différences. Nos résultats serviront aux traducteurs, aux rédacteurs techniques et aux étudiants des LSP afin de mieux comprendre certains éléments discursifs de transmission d'information scientifique dans les deux langues.
\end{abstract}

\begin{abstract}
Genre studies have been mainly focused on the rhetorical structure of research papers. However, genre theorists have not systematically studied either relationships among related genres or interlingual studies between genres. The present study aims at describing and comparing the rhetorical and phraseological structures of abstracts in English and Spanish in order to observe how information is rendered in the two languages under analysis. Our methodology is descriptively performed on a comparable corpus of abstracts in the field of diagnostic imaging and published in well-reputed journals. We will determine composition strategies by means of a semantic and functional approach so as to establish their similarities and differences in this genre. Our results will be primarily of help to translators, technical writers and ESP students to better understand some of the discourse aspects of rendering scientific information in both languages.
\end{abstract}

MOTS-CLÉS/KEYWORDS

abstract, LSP phraseology, rhetoric, scientific genre, subtechnical term

\section{Introduction}

Communicative events are accomplished by a series of interlocking acts realized linguistically (Lewin et al. 2001: 3; Scott and Thompson 2000: 1). Such information has led practitioners in the field of English for Specific Purposes (ESP), English for Academic Purposes (EAP) and Specialized Translation to realize that it is not sufficient to know and understand how to encode and decode individual units of meaning 
in sentences. From this perspective, the essential aim of language study is to describe communication via communicative events, in other words, "by complete instances of language use" (Scott and Thompson 2000: 1). Thus, taking texts in context as objects of study, it is possible to describe their language structures and functions at different levels - rhetorical, phraseological, terminological, grammatical and so on - in order to look for regularities that help the understanding of language events (López Arroyo 2004: 175).

In this sense, this functional analysis has become increasingly important in the description of patterns of behaviour of scientific genres and their constituents. Gledhill (1996) states these formulations are not necessarily grammatical or cohesive devices, but norms of a community which shares certain values and preferred textual structures expressed in rhetorical moves, being a move "a semantic unit according to the writer's purpose" (Swales 1990: 42), "made up of a bundle of linguistic features (lexical meaning, propositional meaning, illocutionary forces, etc.) which give them a uniform orientation and signal the content of discourse in them" (Nwogu 1997: 122).

Research papers and abstracts are two genres that have been studied quite extensively (Dudley Evans 1994, Dudley Evans and St. John 1998, Hyland and Tse 2004, Nwogu 1997, Maingueneau 2002, Posteguillo 1999, Salager-Meyer 1990, 1991, 1992, Samraj 2002, 2005 Swales 1990, 2004 among others). Nevertheless, although these studies are useful to a better understanding of genres as well as to the teaching of linguistic devices to ESP and translation students, technical writers and experts within the fields, most of them are focused on the rhetorical structure of a certain genre intralingually.

However, the functional approach is necessary not only for intralingual studies, but also from an interlingual point of view in order to account for differences and similarities between languages in terms of discourse organization (Marmaridou 1990: 561). In addition, there seems to be a lack of contrastive studies describing language structures at other levels of analysis different from the rhetorical, such as terminological or phraseological. Studies of this kind will reveal similarities inside LSP genres but also, in spite of their seemingly uniform character, a number of language-specific and subject-related differences which might be of great help to translators, technical writers and specialists within a field. (Colina 1997, Gläser 1995, Golebioswski 1998, Granger 2003, Rabadán 2002).

As translators do not receive formal training in any particular LSP, they must set out conscious learning of the LSP lexical and non lexical - such as style, punctuation, grammar, register - elements of the language as well as of the LSP conceptual knowledge (Bowker and Pearson 2002: 19) in order to produce acceptable texts for the target audience. In this sense, contrastive studies and corpus-based studies, as that presented here, might be of great help for the understanding and writing of genres in the target language.

The aim of the present article is to describe and compare the rhetorical and phraseological structures of abstracts, a typical genre produced by the medical discourse community, in English and Spanish, adopting a functional approach. To this end, our analysis will focus on describing these structures first intralingually and then interlingually, looking for differences and similarities. 


\section{Medical Abstracts}

Nord (1997: 54) defines abstracts as a complementary or secondary genre based on a primary text, the Research paper (RP), which may have a metatextual function. On the other hand, abstracts are defined by ISO 214-1976 (E), as an "abbreviated, accurate representation of the contents of a document, without added interpretation or criticism and without distinction as to who wrote the abstract"; that is to say, this type of abstract has been derived from a fully elaborated text by condensing its relevant information (Gläser 1995: 97).

There are two basic types of abstracts, informative or RP abstracts and descriptive. $\mathrm{RP}$ abstracts constitute a well-defined genre with definite attributes and a unique style; it has to be brief, accurate, objective, complete, and intelligible, and it has to be presented in the same format of the RP in order to facilitate the skimming of the RP.

On the other hand, descriptive abstracts help "readers understand the general nature and scope of the RP... but they do not go into a detailed step-by step account of the process involved" (Lorés 2003: 74).

Medical editorial boards typically direct submitters to write informative or RP abstracts, in order to have a "report in miniature" (Jordan 1991: 507). These boards have tried to stipulate the length and structure of RP abstracts within the range of 150 to 250 words and information of scope, methodology, results and conclusions; that is to say, they have to maintain the IMRAD format. However, RP abstracts should not contain direct references to the report they are describing, nor illustrations, tables or bibliographic references.

Well-written RP abstracts enable prospective readers to decide whether it will be worthwhile to read the work in full. Hence, RP abstracts function as advance indicators of the content and structure of the whole text. Nevertheless, sometimes, RP abstracts are the only piece of writing that is read. This is because there are now so many Research Journals that experts do not have time to read all the RPs they contain (Salager-Meyer 1990: 366). Thus, RP abstracts have become a key to the content of the whole text (Sager 1980, Gläser 1995, Göpherich 1995).

\section{Corpus and Methodology}

\subsection{Compiling the corpus}

Our corpus has been built according to pragmatic criteria, i.e. in selecting the texts we took into account their representativity and "popularity" in the field as well as their accessibility and availability in electronic format. Representativity copes with issues such as the "influentialness" of a particular publication, the extent to which this publication is read in the medical community and the currency of the texts (Kennedy 1998: 63, Nwogu 1997: 121), based on the impact factor of the journal. Accessibility, on the other hand, refers to the ease with which texts can be obtained and finally, availability indicates that the journals were available on the web free of charge at the time of compiling.

The medical RP abstracts were extracted from the medical journals Radiology and Radiología on the following basis:

(1) Radiology holds a high impact factor in the Journal Citation Reports, since it was listed in third position among all Radiology, Nuclear Medicine and Medical Imaging journals 
during the year 2000. Radiología is not included in the Journal Citation Reports but it is the most read publication by Spanish radiologists and is included in prestigious national and international medical databases such as IME, Toxline, Bibliomed, EMBASE/ Excerpta Medica.

(2) Radiology is the Official Publication of the Radiological Society of North America (RSNA) and it is indexed in Medline, whereas Radiologia is the Official Publication of the Radiological Society of Spain (SERAM).

(3) The style of the manuscripts of both journals is in accordance with the international committee of medical journal editor's publication.

In order to compile our samples from the journals chosen in accordance with the criteria presented above, we restricted ourselves to all the abstracts of research papers in the subfield of diagnostic imaging published in both journals from the year 2000 to 2004 . It should be noted that review article, case report or clinical trial abstracts were not chosen.

The composition of the "Radiology abstracts corpus" and the "Abstracts de Radiología corpus" is shown in tables 1 and 2 by name of publication, year, and number of words.

TABLE 1

Composition of the "Radiology corpus"

\begin{tabular}{|l|l|l|}
\hline TEXT TYPE & NAME OF PUBLICATION AND YEAR & $\begin{array}{l}\text { NUMBER OF WORDS } \\
48,040\end{array}$ \\
Abstracts & Radiology 2000-2004 & \multicolumn{2}{|l|}{} \\
\hline \multicolumn{2}{|l|}{ Total number of samples 234 } \\
\hline
\end{tabular}

TABLE 2

Composition of the "Radiología corpus"

\begin{tabular}{|l|l|l|}
\hline TEXT TYPE & NAME OF PUBLICATION AND YEAR & $\begin{array}{l}\text { NUMBER OF WORDS } \\
\text { Abstracts }\end{array}$ \\
\hline \multicolumn{2}{|l|}{ Radiology 2000-2004 }
\end{tabular}

From these data, it can be inferred that the size and the samples comprised in both "abstracts corpora" are not the same and, consequently, we will have to adapt the number of samples and words when applying our methodology. This difficulty has been overcome resorting to percentages as can be shown in tables 5 and 6 .

\subsection{Methodology}

As we have mentioned, the aim of our paper was to describe some of the representative, favourite according to Bondarko's study (1991), rhetorical and phraseological structures in RAs published in two medical journals. We assumed that linguistic patterns or genre conventions share both a basic meaning and a function between languages but languages differ in the way information is distributed. In this sense, Rabadan (2002) maintains that languages show a preference for particular rhetoric strategies, observed in the distribution and frequency of certain structural, semantic and pragmatic rhetorical patterns. Accordingly, knowing and understanding these micro and macrolinguistic patterns of behavior seem to be essential not only for those experts whose native language is not English, but also for translators and technical 
writers; if languages use different resources to express both meaning and form, translators, technical writers and experts should be aware of them, so that their researches and advances can be successfully reported and accepted by other members of the discourse community.

Hence, once the corpus was compiled, the next step was to describe how semantic strategies were present in some phraseological structures of RP abstracts in our corpora and the way these structures influenced the rhetoric.

\subsection{Identifying the phraseology}

We define LSP phraseology as the study and compilation of terminological word combinations, also called 'phraseological units,' (PUs) that occur frequently in technical and scientific language, such as collocations, irreversible binomials, idioms, routine formulae and combinatorial patterns (Méndez-Cendón 2002).

Our assumption was that by identifying key subtechnical terms in both corpora we would be able to detect some relevant PUs used to structure the information in the section. Subtechnical terms may be defined as vocabulary that is used in general language but has a specialized and restricted meaning in certain disciplines and which may vary in meaning across disciplines (Dudley Evans and St. John 1998: 82-83); for example, the words findings, examination and study in the medical field.

To extract the phraseology from the corpora we used WordSmith Tools, a software package devised for looking at how words behave in texts. Using the WordList Tool option we were first able to extract the most frequently used words in each corpora. Tables 3 and 4 list the words by frequency of occurrence in each section (functional words have been omitted from the lists).

TABLE 3

Word lists from the "Abstracts de Radiología corpus" sorted by frequency of occurrence

\begin{tabular}{|l|l|}
\hline ABSTRACTS & 191 \\
\hline PACIENTES & 88 \\
\hline TC & 79 \\
\hline RM & $\mathbf{6 8}$ \\
\hline ESTUDIO & 66 \\
\hline DIAGNÓSTICO & 56 \\
\hline ECOGRAFÍA & 45 \\
\hline CONTRASTE & 34 \\
\hline BIOPSIA & 31 \\
\hline ESTENOSIS & 31 \\
\hline TRATAMIENTO & 30 \\
\hline PATOLOGÍA & 29 \\
\hline COMPUTARIZADA & 29 \\
\hline PREDICTIVO & 26 \\
\hline MAGNÉTICA & 26 \\
\hline RESONANCIA & 26 \\
\hline VALORAR & 25 \\
\hline IMAGEN & 23 \\
\hline TOMOGRAFÍA & 22 \\
\hline IMÁGENES & 22 \\
\hline PACIENTE &
\end{tabular}




\begin{tabular}{|l|l|}
\hline SEGUIMIENTO & 21 \\
\hline ESTUDIOS & $\mathbf{2 0}$ \\
\hline SOSPECHA & 19 \\
\hline EXPLORACIONES & 4 \\
\hline EXPLORACIÓN & 2 \\
\hline EXPLORADOS & 2 \\
\hline EXAMEN & 1 \\
\hline EXÁMENES & 1 \\
\hline
\end{tabular}

TABLE 4

Word list from the abstracts of the "Radiology abstracts corpus" sorted by frequency of occurrence.

\begin{tabular}{|c|c|}
\hline \multicolumn{2}{|l|}{ ABSTRACTS } \\
\hline PATIENTS & 643 \\
\hline IMAGING & 371 \\
\hline $\mathrm{CT}$ & 303 \\
\hline CONTRAST & 190 \\
\hline IMAGES & 182 \\
\hline ANGIOGRAPHY & 136 \\
\hline FINDINGS & 123 \\
\hline ARTERIAL & 113 \\
\hline MAGNETIC & 99 \\
\hline RESONANCE & 96 \\
\hline HEPATIC & 93 \\
\hline DISEASE & 78 \\
\hline STENT & 71 \\
\hline TUMOR & 71 \\
\hline VASCULAR & 71 \\
\hline ECHO & 67 \\
\hline PATIENT & 66 \\
\hline DETERMINE & 65 \\
\hline DIAGNOSIS & 65 \\
\hline DETECTION & 62 \\
\hline SHOWED & 61 \\
\hline STUDIES & 58 \\
\hline ACCURACY & 57 \\
\hline OBTAINED & 57 \\
\hline DIAGNOSTIC & 56 \\
\hline TREATMENT & 55 \\
\hline EVALUATE & 54 \\
\hline DOPPLER & 52 \\
\hline ULTRASONOGRAPH+ & 52 \\
\hline $\mathrm{CM}$ & 51 \\
\hline EVALUATED & 49 \\
\hline IMAGE & 49 \\
\hline HELICAL & 47 \\
\hline PLACEMENT & 46 \\
\hline STUDY & 46 \\
\hline SURGICAL & 46 \\
\hline
\end{tabular}

These lists reveal that study and estudio are two subtechnical terms which often occur in RP abstracts in Radiology and Radiología. In addition, preliminary research revealed that these two terms present two different meanings in the field of diagnostic imaging 
(Méndez Cendón and López Arroyo 2003). Doctors use them in RPs and in RP abstracts both to refer to "works, papers and research" published in the field and to designate "a diagnostic examination or exploration," for example, a computed tomography (CT) study or a magnetic resonance (MR) study.

\subsection{Identifying the rhetoric}

Previous studies (López Arroyo 2001; Méndez Cendón and López Arroyo 2003) have shown that abstracts do not include all the moves and steps of the RPs from which they derive, because of their concise nature. Hence, whereas RPs include 3 or 4 moves for each section, RP abstracts include 2 or 3 optional moves.

In order to gain a more clear insight into the schematicity of moves and submoves or steps within RP abstracts, our intention here is to describe and compare briefly what each of those moves consists of. This can only be done by a comparison of the distribution of moves and steps between RPs and RP abstracts; in order to do so, and for the purposes of the present study, we have adopted Nwogu's (1997) schematic structure of information for RPs as a starting point, as it develops a rhetorical structure for medical research papers.

As we have mentioned above, RPs and RP abstracts have the specific standard format known as IMRAD; however, each of these sections contains an internal ordering of the information presented, which writers should follow in order to have their RPs admitted for publication.

The Introduction is an initiation section used to present the information by means of introducing background information of the topic of discourse, by relating other studies with the piece of research presented in the paper and, finally, by introducing new insights into the problem described previously and contrasting it with already known methodologies. RP Abstracts only include references to the research authors are presenting in their papers. Figure 1 shows the rhetorical distribution of RPs and $\mathrm{RP}$ abstracts for this section:

FIGURE 1

Rhetorical distribution in RP and RP abstract's Introductions

\begin{tabular}{|c|c|c|c|}
\hline \multicolumn{3}{|c|}{ Research Papers } & Abstracts \\
\hline \multirow{7}{*}{$\begin{array}{l}\text { Introductions } \\
\text { (Presentation) }\end{array}$} & Moves & Steps & \\
\hline & \multirow{2}{*}{$\begin{array}{l}\text { 1. Background Information } \\
\text { (References to) }\end{array}$} & $\begin{array}{l}\text { Established knowledge in } \\
\text { the field }\end{array}$ & \\
\hline & & Main research problems & \\
\hline & \multirow{2}{*}{$\begin{array}{l}\text { 2. Reviewing Related } \\
\text { Research (References to) }\end{array}$} & Previous research & \\
\hline & & $\begin{array}{l}\text { Limitations of previous } \\
\text { research }\end{array}$ & \\
\hline & \multirow{2}{*}{$\begin{array}{l}\text { 3. New Research } \\
\text { (References to) }\end{array}$} & Research purpose & $\begin{array}{l}\text { Research } \\
\text { Purpose }\end{array}$ \\
\hline & & Main research procedure & $\begin{array}{l}\text { Main research } \\
\text { procedure }\end{array}$ \\
\hline
\end{tabular}

The section containing the Methods (see figure 2 below) can be defined as a description of procedures. Authors will focus on the perspective adopted for the achievement 
of significant results as well as on the apparatus that need to be used to interpret those results. On the other hand, $\mathrm{RP}$ abstracts only include an introduction to the materials and methods used in the research (such as data size or criteria for data collection) and a description of the experimental procedures:

FIGURE 2

Comparison of the rhetorical distribution in RP and RP abstract's Materials and Methods

\begin{tabular}{|c|c|c|c|}
\hline \multicolumn{3}{|l|}{ Research Papers } & Abstracts \\
\hline \multirow{11}{*}{$\begin{array}{l}\text { Materials and } \\
\text { Methods } \\
\text { (Description) }\end{array}$} & Moves & Steps & \\
\hline & \multirow{3}{*}{$\begin{array}{l}\text { 4. Data-Collection } \\
\text { Procedure }\end{array}$} & Source of Data & Source of Data \\
\hline & & Data Size & Data Size \\
\hline & & $\begin{array}{l}\text { Criteria for Data } \\
\text { collection }\end{array}$ & $\begin{array}{l}\text { Criteria for Data } \\
\text { collection }\end{array}$ \\
\hline & \multirow{3}{*}{$\begin{array}{l}\text { 5. Experimental } \\
\text { Procedures }\end{array}$} & Research apparatus & Research apparatus \\
\hline & & Experimental process & Experimental process \\
\hline & & Criteria for success & \\
\hline & \multirow{4}{*}{$\begin{array}{l}\text { 6. Data-Analysis } \\
\text { Procedure }\end{array}$} & Terminologies & \\
\hline & & Data classification & \\
\hline & & $\begin{array}{l}\text { Analytical instrument/ } \\
\text { procedure }\end{array}$ & \\
\hline & & $\begin{array}{l}\text { Modification to } \\
\text { instrument/ procedure }\end{array}$ & \\
\hline
\end{tabular}

Once the section stating the Methods to be observed has been completed, the intention of the author should be, and normally is, to introduce the reader to the results obtained in the study. Therefore, the next section is that of Results, which includes visual information such as graphs, tables and pictorials and has a rhetorical distribution as follows in figure 3:

FIGURE 3

Comparison of the rhetorical distribution in RP and RP abstract's Results

\begin{tabular}{|c|c|c|c|}
\hline \multicolumn{3}{|l|}{ Research Papers } & Abstracts \\
\hline \multirow{5}{*}{$\begin{array}{l}\text { Results } \\
\text { (Indicate, } \\
\text { Highlight, Report, } \\
\text { Present) }\end{array}$} & Moves & Steps & \\
\hline & \multirow{3}{*}{$\begin{array}{l}\text { 7. Consistent } \\
\text { Observation }\end{array}$} & Overall Observation & \\
\hline & & Specific Observation & Specific Observation \\
\hline & & $\begin{array}{l}\text { Accounting of } \\
\text { Observation made }\end{array}$ & $\begin{array}{l}\text { Accounting of } \\
\text { Observation made }\end{array}$ \\
\hline & $\begin{array}{l}\text { 8. Non-Consistent } \\
\text { Observation }\end{array}$ & Negative Results & \\
\hline
\end{tabular}

Finally, the last section that Nwogu (1997) describes in the structure of RPs is that of Discussion in which authors state, highlight or explain the results of their study. RP abstracts include a section called Conclusions in which authors interpret the results of their research and its implications in the field; consequently, this section can be compared with that of research conclusions within the Discussion section as illustrated in the following figure: 
FIGURE 4

Comparison of the rhetorical distribution in RP and RP abstract's Discussion

\begin{tabular}{|c|c|c|c|}
\hline \multicolumn{3}{|l|}{ Research Papers } & Abstracts \\
\hline \multirow{9}{*}{$\begin{array}{l}\text { Discussion } \\
\text { (Explain, } \\
\text { Highlight, State, } \\
\text { Interpret) }\end{array}$} & Moves & Steps & \\
\hline & $\begin{array}{l}\text { 9. Overall Research } \\
\text { Outcome }\end{array}$ & & \\
\hline & \multirow{5}{*}{$\begin{array}{l}\text { 10. Specific } \\
\text { Research } \\
\text { Outcome }\end{array}$} & State & \\
\hline & & Indicate significance & \\
\hline & & Interpret & \\
\hline & & Contrast present and previous & \\
\hline & & Limitations & \\
\hline & \multirow{2}{*}{$\begin{array}{l}\text { 11. Research } \\
\text { Conclusions }\end{array}$} & Implications & Implications \\
\hline & & Further Research & Further Research \\
\hline
\end{tabular}

Therefore, what should differentiate RPs and RP abstracts is the amount of information they include for each of the sections within them. Accordingly, the editorial committees for Radiology and Radiología restrict RP abstracts to 250 words or less, according to the Uniform Requirements for medical Journals established by the Journal of the American Medical Association (JAMA), and impose a variation on their external structure, naming the separate sections differently and also ascribing to them particular specificities that have to be observed; these sections should correspond to four separate paragraphs under the headings of Purpose, Materials and Methods, Results, Conclusions for Radiology and Objetivos, Materiales y Métodos, Resultados and Conclusión for Radiología.

With these prerequisites in mind, the purpose of our research has been to allocate the external structure of RPs to RP abstracts in order to confirm that such parallelism is to be achieved; yet, as our study has adopted a descriptive approach, our methodology has been carried out considering the editorial committee constraints as the tertium comparationis, or token, against which all the results should be contrasted.

Tables 5 and 6 show the external structure of the corpus of the corpus of RP abstracts of both journals. These results show that Radiología sometimes tend to accept descriptive abstracts (12.17\% of the samples in that corpus), that is to say, abstracts describing the scope of the text, but not containing extensive data and not designed to replace the RP. The Spanish corpus also shows that authors seem to be less conscious of the Editorial Requirements of the Journal than authors submitting their RPs to Radiology; samples complying with the specific Editorial Requirements, in terms of naming the sections of the abstract, are less frequent in the Spanish corpus than in the English corpus as $12.26 \%$ of the Spanish samples do not name the sections vs. $6.41 \%$ of the samples in the English corpus.

TABLE 5

External Structure of the Abstracts de Radiología corpus

\begin{tabular}{|l|c|}
\hline EXTERNAL STRUCTURE. Radiología: Abstracts (192 muestras) \\
\hline Editorial Requirements & $71.3 \%$ \\
\hline Samples not complying with the naming & $12.26 \%$ \\
\hline IMRAD & $6.26 \%$ \\
\hline Descriptive abstracts & $12.17 \%$ \\
\hline
\end{tabular}


TABLE 6

External Structure of the Radiology Abstracts Corpus

\begin{tabular}{|l|r|}
\hline EXTERNAL STRUCTURE. Radiology: Abstracts (192 samples) \\
\hline Editorial Requirements & $80.76 \%$ \\
\hline Samples not complying with the naming & $6.41 \%$ \\
\hline IMRAD & $4.2 \%$ \\
\hline Descriptive Abstracts & $5.98 \%$ \\
\hline
\end{tabular}

\section{Results and Discussions}

Using the WordSmith's Concord Tool option, which produces Kwic concordances in context (KWIC), we were able to extract some relevant PUs. These PUs are combinatorial patterns, that is, words and structures which are regularly associated with the subtechnical term and which contribute to its meaning (Hunston and Francis 2000: 37). A pattern can be identified if a combination of words occurs relatively frequently in the corpus.

We found the concept of "collocational framework," in the sense of Renouf and Sinclair (1991: 128), extremely useful to define the combinatorial patterns found to express the moves within RAs. Collocational frameworks consist of a discontinuous co-occurrence of two grammatical words, for example $a+?+$ of (in the case of the present paper: $a+s t u d y+o f$ ). The collocational frameworks identified in Radiology are normally part of a longer structure.

Our results only show those combinatorial patterns which are significantly different in English and Spanish in RP abstracts. The following figure summarizes the interlinguistic equivalences that can be inferred from our phraseological analysis in the abstracts corpora:

FIGURE 5

Interlingual equivalences found in abstracts of Radiology and Radiología

\begin{tabular}{|l|l|l|}
\hline Moves & Radiology & Radiología \\
\hline IntroductionMove 3 & $\begin{array}{l}\text { Verbs expressing evaluation } \\
+ \text { noun group + in a } \\
\text { premodifier (prospective) } \\
\text { study }\end{array}$ & $\begin{array}{l}\text { Verbs expressing evaluation + noun } \\
\text { group (el papel/la utilidad) + de X aparato } \\
\text { type of apparatus) + en el estudio (in } \\
\text { the study) + de X pacientes (of X patients) } \\
+ \text { con X patología (with a particular } \\
\text { pathology) }\end{array}$ \\
\hline $\begin{array}{l}\text { Materials and } \\
\text { Mothods } 4\end{array}$ & $\begin{array}{l}\text { Type of study+ passive voice } \\
\text { in the simple past + in X } \\
\text { patients }\end{array}$ & $\begin{array}{l}\text { Estudio }(\text { study) + postmodifiers }+ \\
\text { nonfinite clause/verbless clause }\end{array}$ \\
\hline Results Move 7 & $\begin{array}{l}\text { Type of image examination } \\
+ \text { perform (simple past in } \\
\text { the passive voice) }+ \text { in X } \\
\text { patients }\end{array}$ & $\begin{array}{l}\text { Tipo de estudio (Type of study) + } \\
\text { demostró / mostró / confirmó (showed, } \\
\text { confirmed) + type of lesion }\end{array}$ \\
\hline $\begin{array}{l}\text { Conclusion } \\
\text { Move 11 }\end{array}$ & $\begin{array}{l}\text { Premodifier }+ \text { study }+ \\
\text { simple present in the passive } \\
\text { voice }\end{array}$ & $\begin{array}{l}\text { Tipo de estudio (Type of study) + } \\
\text { constituir, ser, mostrar) verbs expressing } \\
\text { evaluation in the simple present + field } \\
\text { under study }\end{array}$ \\
\hline
\end{tabular}


As we have mentioned, RP abstracts published in Radiology or in Radiología are required to include a first section called Purpose/Objetivo as an introductory move in which they state the research purpose. Our phraseological analyses show that both sections are used to state the research purpose by means of a non finite clause of purpose and including a verb expressing an assessment (identify, compare, determine or valorar, evaluar, determinar - assess, determine - in Spanish) and, hence, this section can be compared to the third move of RPs Introductions (references to new research).

(1) PURPOSE: To identify radiographic signs of mucosal damage by comparing hysterosalpingography with salpingoscopy in a prospective study.

(2) Valorar el papel de la ecografía Doppler color (EDC) en el estudio prequirúrgico de pacientes con varices. [To evaluate the use of color-Doppler echography in the study of patients suffering from varicose veins. Our translation]

Nevertheless, regarding the Materials and Methods section, the Radiology abstracts corpus shows a description of the data collection procedure (source of data, data size or criteria for data inclusion) by means of verbs like perform in the passive voice ( $45 \%$ of the samples); on the other hand, the abstracts de Radiología corpus tends to include verbless clauses or non-finite clauses in this section (23\% of the samples):

(3) MATERIALS AND METHODS: A prospective study of helical CT of the abdomen was performed by using (...) contrast material in 221 patients.

(4) MATERIALES Y MÉTODOS: Estudio observacional, prospectivo, unicéntrico, no controlado, abierto, fase IV. [A prospective, observational, non-controlled, open, phase IV study. Our translation]

As can be observed in the previous examples, a telegraphic style is used to describe the study carried out by Spanish authors, whereas the Radiology abstracts corpus includes a passive voice as its favorite structure for this move.

At this point of our analysis, certain differences can be stated in the genre under study. A previous study on the phraseological devices of RPs (López Arroyo and Méndez Cendón, 2006 forthcoming) revealed a preference for examination in English with the meaning of study in the Results section. However, whereas English RP abstracts follow the same trend of RPs, the Spanish RP abstracts do not include this combinatorial pattern:

(5) RESULTS: Forty (74\%) patients had benign adnexal masses, and 14 (26\%) had malignant masses (...) All breast metastases to the ovary were bilateral solid masses at histopathologic examination and occurred in women with stage IV breast carcinoma at the time of US.

(6) El seguimiento se realizó mediante ecografía y portografía directa. Además, un estudio histopatológico en dos pacientes confirmó los resultados. [The follow-up was carried out with direct echography and portography. The results were verified by a histopathologic study in two patients. Our translation]

An analysis of the meaning of the terms examination and study reveals a more general meaning for the Spanish subtechnical term than for the English one. In addition, a distinguishing feature of this Spanish term is that they act as inanimate subjects of active verbs, such as demostrar, mostrar and confirmar (demonstrate, show, confirm). This phenomenon is known as "personification" in scientific language. Therefore, the combinatorial pattern for move 7 (see figure 5) is very typical of this section in the Spanish corpus and it indicates consistent observations made in the study. 
Finally, the Discussion section of RPs corresponds to the Conclusion section of RP abstracts. The analysis of our corpus shows us a main difference in meaning between the corpora under study; while Spanish samples are likely to include conclusions to the research presented in the paper, English samples indicate conclusions related to the field of diagnostic imaging in general. Furthermore, in the Radiology abstracts corpus authors use a simple present tense in the passive voice for this move, a striking strategy because past tenses were used for the other moves:

(7) Further study is needed to determine longer term outcomes.

(8) Los estudios de imagen prequirúrgicos constituyen un pilar fundamental para establecer una correcta valoración de los mismos y optimizar su tratamiento. [Diagnosis imaging studies are essential to establish the appropriate assessment and to improve treatments. Our tanslation]

\section{Conclusion}

Our study has provided evidence that combinatorial patterns are important for the development of information in English and Spanish medical RP abstracts. From the lexical point of view, the language used in Radiology's RP abstracts includes fixed and repetitive combinatorial patterns for Nwogu's moves. On the contrary, the language in Radiologia's RP abstracts is much less formulaic and allows more variation. Therefore, lexical repetition is lower in Radiología than in Radiology, and this fact is directly related to the inherent nature of the Spanish language.

On the other hand, from a grammatical viewpoint, the use of some verbal tenses in both publications is remarkable. Whereas English always uses the passive voice in the simple past for move 4, Spanish uses non-finite verbless clauses. It is our impression that the telegraphic style makes the discourse of Radiología more dynamic, involving the reader more actively than does the past tense.

This grammatical analysis was further reinforced with the findings already shown in the results of our lexical analysis. Thus, our analysis also confirmed that the cooccurrence of inanimate subjects with animate verbs ("personification") is a characteristic feature of the Spanish publication, generating different patterns in the Materials and Methods and Results sections.

Finally, our lexico-grammatical analysis has been graded up to both the phraseological and rhetorical levels, notwithstanding the analysis of the semantic aspects involved; this is best illustrated by the analysis of the subtechnical term examination, which is used in a more restricted sense than study in the Results section. Examination indicates a specific type of radiological study undergone by the patient. On the contrary, the term estudio is used in Radiología to encompass the meanings of study and examination. Therefore, estudio is used as a hyperonym word or a generic term, whereas examination is used as a hyponym or specific term. This finding may suggest that Spanish authors do not always assume that the readers have the same level of expertise they do. On the contrary, English authors use specific terms in the language of Radiology, with an abundance of premodification and complex noun phrases, implying that the audience has the same level of knowledge as the authors of the papers.

As far as the rhetoric is concerned, whereas in Radiology the IMRAD pattern is always followed and therefore the journal is fully consistent with the Uniform 
Requirements Submitted to Biomedical Journals, authors publishing their research in Radiología seem to be less conscious of the Editorial Requirements of the Journal in terms of naming the sections of the RP abstract. In addition, descriptive abstracts have been found in the Spanish corpus (12.7\% of the samples) when editorial boards specifically state that RP abstracts are to be written.

Our analysis has demonstrated the important role that electronic corpora play for a relevant linguistic description of any specific text genre. In addition, it has shown that the phraseology of the text genre is essential for producing coherent and logically organized target texts and to ensure their quality in the target language and culture. We believe that our methodology could be used with other subtechnical terms, other text genres and other languages in order to develop some methodological guidelines that could be of valuable use to non-native specialists and translators.

\section{NOTE}

* This paper has been written within the research project falta incluir referencias. We would like to thank Prof. Roda P. Roberts of the University of Ottawa for her help and constructive comments on the paper.

\section{REFERENCES}

Bondarko, A.V. (1991): Functional grammar. A field approach, Amsterdam, John Benjamins.

Bowker, L. and J. Pearson (2002): Working with specialized language: A practical guide to using corpora, London, Routledge.

Colina, S. (1997): "Contrastive rhetoric and text-typological conventions in translation teaching," Target 9-2, p. 353-371.

Dudley Evans, T. (1994): "Genre analysis: An approach to text analysis for ESP" in Coulthard, M. (ed.): Advances in written text analysis, London, Routledge, p. 219-228.

Dudley Evans, T. and M. Sт. John (1998): Developments in English for Specific Purposes: A multidisciplinary approach, Cambridge, C.U.P.

Editorial Committee of Medical Journal Editors (2001): Uniform requirements for manuscripts submitted to biomedical journals, in <www.icmje.org $>$.

GLÄSER, R. (1995): “The LSP genre abstract revisited” in GLÄSER, R. (ed.): Linguistic features and genre profiles of scientific English, Frankurt am Main, Verlag, p. 97-105.

Gledhill, C. (1996): "Collocation and the rhetoric of scientific ideas. Corpus linguistics as methodology for genre analysis," in ASIS'96 Proceedings.

Golebiowski, Z. (1998): "Rhetorical approaches to scientific writing: an English-Polish contrastive study," Text 18, p. 67-102.

GöPfERICH, S. (1995): "A pragmatic classification of LSP texts in science and technology," TARGET 7-2, p. 305-326.

GRANGER, S. (2003): “The corpus approach: A common way forward for Contrastive Linguistics and Translation Studies" in Granger, S, Lerot, J. and S. Petch-Tyson (eds): Corpus-based approaches to Contrastive Linguistics and Translation Studies, Amsterdam, Rodopi, p. 17-30.

Hunston, S. and G. Francis (2000): Pattern grammar. A corpus-driven approach to the lexical grammar of English, Amsterdam, John Benjamins.

HyLAND, K. and P. Tse (2005): "Hooking the reader: A corpus study of evaluative that in abstracts," ESP 24-2, p. 123-139.

JORDAN, M.P. (1991): “The linguistic genre of abstracts," in VolPR, D. (ed): The Seventeenth LACUS Forum 1990, Lake Bluff, Illionis: LACUS, p. 507-527.

Kennedy G. (1998): An introduction to corpus linguistics, London \& New York, Addison Wesley Longman. 
Lewin, B.A, Fine, J. and L. Young (2001): Expository discourse: A genre based approach to social science research texts, London, Continuum.

López-Arroyo, B. (2001): Estudio descriptivo comparado Inglés-Español de la representación del conocimiento en los abstracts de las Ciencias de la Salud, Valladolid, Universidad de Valladolid.

López-Arroyo, B. (2004): "English and Spanish medical research papers and abstracts: How differently are they structured?," in BRAVO, J.M. (ed.): New spectrum of Translation Studies, Valladolid: Universidad de Valladolid, p. 175-193.

López-Arroyo, B. and B. Méndez-Cendón (2006): "English/Spanish contrastive analysis of phraseological and rhetorical devices in medical research papers," ESP (forthcoming).

Lorés SAnZ, L. (2003): "On the rhetorical structures of abstracts," in Luque, G, Bueno, A and G. Tejada (eds): Languages in a global world, Jaén, Universidad de Jaén, pp. 73-80.

Maingueneau, D. (2002): “Analysis on academic genre," Discourse Studies 4, p. 319-342.

Marmaridou, S (1990): "Contrastive Analysis at discourse level and the communicative teaching of languages," in Fisıak, J. (ed): Further insights into Contrastive Analysis, Amsterdam, John Benjamins, p. 561-571.

Méndez-Cendón, B. (2002): Phraseology in medical research papers written in English, Ann Arbor, UMI Dissertation Services.

Méndez-Cendón, B and B. López-Arroyo (2003): "Intralinguistic analysis of medical research papers and abstracts. Rhetorical and phraseological devices in scientific information," Terminology 9-2, p. 247-269.

Nord, C. (1997): Translating as a purposeful activity, Manchester, St. Jerome.

Nwogu, K.N. (1997): “The medical research paper: Structure and functions," ESP 16-2, p. 119138.

Posteguillo, S. (1999): “The schematic structure of computer science research articles," ESP 18-2, p. 139-158.

RABADÁN, R. (2002): “Análisis contrastivo y traducción especializada inglés-español: el programa ACTRES," in Bravo Gozalo, J.M (ed.), Nuevas perspectivas de los Estudios de Traducción, Valladolid, Universidad de Valladolid, p. 35-56.

Renouf, A. and J. Sinclair (1991): "Collocational frameworks in English," in Aijmer, K. and B. Altenberg (eds): English corpus linguistics, London, Longman, p. 128-143.

Salager-Meyer, F. (1990): "Metaphors in medical English prose: A comparative study with French and Spanish," ESP 9-2, p. 145-159.

Salager-Meyer, F. (1991): "Medical English abstracts: How well are they structured?," Journal of the American Society of Science 42-7, p. 528-531.

Salager-Meyer, F (1992), "A text-type and move analysis study of verb tense and modality in medical English abstracts," ESP 11, p. 149-170.

SAMraJ, B. (2002): "Introductions in research articles: Variations across disciplines," ESP 21-1, p. 1-17.

SAmRAJ, B. (2005): "An exploration of a genre set: Research article abstracts and introductions in two disciplines," ESP 24-2, p. 141-156.

SAGER, J.C. et al. (1980): English Special Languages, Wiesbaden, Bransletter Verlag.

Swales, J. (1990): Genre Analysis, Cambridge, C.U.P.

Swales, J. (2004): Research Genres, Cambridge, C.U.P.

Sсотт, M. and M. Тномpson (2000): “Introduction. Why 'patterns of text'?"' in Scotт, M. and G. Thompson (eds): Patterns of text. In honour of Michael Hoey, Amsterdam, John Benjamins, p. 1-7.

WordSmith Tools, Version 3.0. Programmed by Mike Scott. Oxford: Oxford University Press, in $<$ www1.oup.co.uk/elt/catalogue/ Multimedia/ WordSmithTools3.0/ download.html>. 